\title{
The management of a positional default of atlas in a patient with cervicogenic headache: A case report
}

\author{
Rob Sillevis ${ }^{1 *}$ and Karen Wyss ${ }^{2}$ \\ F1, 33914, USA \\ ${ }^{2}$ Private Practice (Integrated Therapy Practice PC), 1265 S Lake Park Ave. Hobart, In 46342, USA
}

${ }^{1}$ Private Practice (Integrated Therapy Practice PC), Adjunct Faculty: University of St. Augustine, FL/ Florida Golf State University, 3325 Sw 5th Place. Cape Coral

Cervicogenic headache $(\mathrm{CH})$ is a unilateral headache that can spread to the frontal- temporal and orbital regions and has been defined by the International Headache Society as "pain, referred from a source in the neck" [1]. The prevalence of $\mathrm{CH}$ is around $4 \%$ in the general population ranging from $15 \%$ to $20 \%$ of all headaches [2-4]. Although the exact mechanism remains elusive, there appears to be a correlation between mechanical dysfunction of the high cervical spine and the development of $\mathrm{CH}$ [4-7].

The C2 dorsal ganglion is positioned within the confinement of the $\mathrm{C} 2$ foramen between the inferior margin of the posterior arch of atlas and the superior margin of the lamina of axis and occupies about $76 \%$ of the available foraminal height $[8,9]$. The foraminal space might become compromised during movement of atlas thereby directly irritating the $\mathrm{C} 2$ ganglion, which has been related to the development of $\mathrm{CH}[8,9]$. The ligaments in the upper cervical segments help guide normal movement patterns, and provide passive stability [10]. Ligaments display relative flexibility around a "neutral" position [11-13]. It appears that the suboccipital joints display a larger neutral zone compared to the lower cervical segments, allowing relative small forces of the suboccipital musculature to create motion of atlas within the Atlanto-Axial (AA) joint [11,14-17]. An anatomical connective tissue relationship between the rectus capitus posterior minor and the dura mater has been identified [18,19]. Rocabado [20] found a similar soft tissue connection between the posterior arch of atlas and the dura mater, supporting the notion that anatomical position and motion of atlas and axis could directly influence the neuromenigeal system [19].

Fielding and Hawkins introduced the term atlanto-axial rotatory fixation to describe a phenomenon in which the atlas remains rotated relative to the axis and occiput after undergoing trauma to the cervical spine [21]. Local muscle spasms with or without the presence of a swollen or disrupted joint capsule, or cartilaginous structures impinged in the AA joint could potentially maintain a rotatory positional default position of atlas [21-24]. Based on anatomical relationships atlas position can affect both ligamentous and muscular functioning in the high cervical region and might contribute to the development or maintaining of $\mathrm{CH}$. The purpose of this case study is to propose the hypothesis that atlas can be in a rotatory positional default position and to demonstrate the management of this clinical phenomenon in a patient with $\mathrm{CH}$ following a whiplash injury.

\section{Patient characteristics}

The patient, a 20 -year-old ectomorphic female, presenting two months following a motor vehicle accident. She developed immediate pain in the cervical region and a headache; therefore, she was evaluated in the ER and underwent a physical and radiological assessment (Figure 1). She was evaluated by a neurologist and diagnosed with cervicogenic headaches, $\mathrm{He}$ referred her for physical therapy. Her subjective complaints revealed daily headaches located in the occipital region $(\mathrm{R}>\mathrm{L})$, radiating supra-orbital and posterior neck pain $(\mathrm{R}>\mathrm{L})$. The pain was described as "sharper, especially with left rotation". Additionally, forward and backward bending of the neck, and performing overhead activities provoked her pain. Her pain prevented participation in normal daily and recreational activities. She denied dizziness, numbness in any of the extremities, balance difficulties, or changes in vision/hearing/smell. She denied any previous history of headaches, cervical dysfunction, or trauma and she reported an unremarkable medical history with a negative general health screen for the presence of red or yellow flags; therefore further examination of this patient was appropriate.

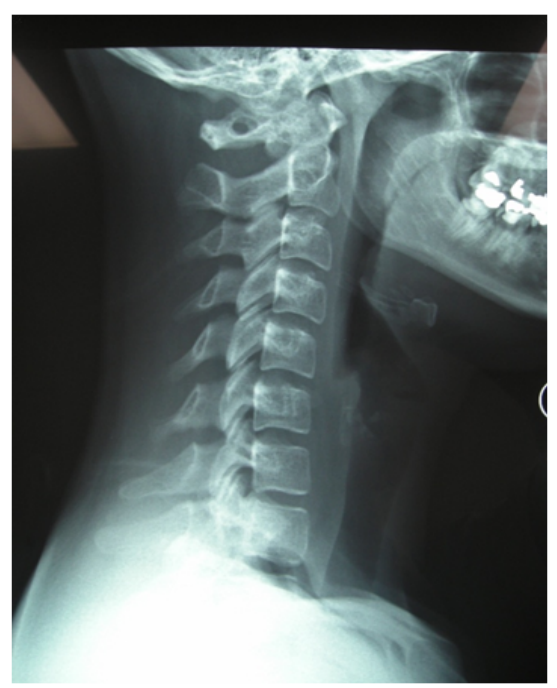

Figure 1. Lateral CSA radiograph.

Correspondence to: Rob Sillevis, Private practice (Integrated Therapy Practice PC), Adjunct Faculty, University of St. Augustine, FL/ Florida Golf State University, 3325 Sw 5th Place. Cape Coral Fl, 33914, USA, Tel: 219-8054823; Fax: 239-2571485; E-mail: r.sillevis@comcast.net

Received: September 27, 2015; Accepted: October 17, 2015; Published: October 19,2015 


\section{Examination}

The patient completed self- report measures, followed by a physical examination.

\section{Self-reported measures (Table1)}

The visual analog scale (VAS) was used to assess pain at the time of the evaluation [25]. The validity and reliability of the VAS have been previously reported for patients with acute and chronic pain [26]. She reported her pain at its best at $35 \mathrm{~mm}$ and at its worst at $90 \mathrm{~mm}$ on a VAS. At the time of her evaluation the pain was at $84 \mathrm{~mm}$.

The Neck Disability Index (NDI) was used to measure her selfreported level of disability [27-29]. Content, construct validity, and reliability of the NDI have been previously shown in patients with neck pain $[30,31]$. Although the maximum score is 50 , it was chosen to calculate this patient's score as a percentage, in which higher scores would indicate higher levels of disability. The patient scored an NDI of $68 \%$ at the time of her evaluation.

\section{Physical examination}

The patient ambulated normally and appeared uncomfortable during her intake interview. Visual inspection revealed a forward head placement with a suboccipital extension position and bilateral shoulder protraction $(\mathrm{R}>\mathrm{L})$. Forward head position can be attributed to a variety of musculoskeletal dysfunctions, which include neck pain, headaches, and craniofascial pain [32-37]. Active range of motion (AROM) was used as a screening test and assessed in sitting [38]. A description of the measurement protocol can be found in Table 1 . The patient demonstrated decreased forward bending of $40^{\circ}$ limited by tightness and pain and backward bending was limited at $15^{\circ}$ by pain. Rotation left was $42^{\circ}$ and rotation right was $65^{\circ}$. Side bending left was $32^{\circ}$ and right was $40^{\circ}$. She reported neck pain during the Spurling's test and the right Quadrant test; however, no radiating symptoms were reported, indicating possible involvement of the facet joints, which could account for the AROM loss [39]. The seated Sharp-Purser and supine alar ligament tests were negative so it was assumed that the high cervical ligamentous system was intact. She displayed a negative bilateral upper limb tension test, normal bilateral muscle stretch reflexes in the UE's, negative cranial nerve testing [39], and normal bilateral myotomal strength in the upper quadrant. Palpation revealed hypertonicity of the suboccipital triangle $(\mathrm{R}>\mathrm{L})$, bilateral scalene $(\mathrm{R}>\mathrm{L})$, levator scapulae $(\mathrm{R}>\mathrm{L})$, and trapezius muscles. Sensitivity to touch was present at the nuchal line, suboccipital muscles $(\mathrm{R}>\mathrm{L})$, and the right facet capsules of $\mathrm{C} 2-\mathrm{C} 3$ and $\mathrm{C} 5-\mathrm{C} 6$. Palpation for position revealed what appeared to be a rotation of atlas in relationship to the occiput and axis, which was evident by a relative anterior position of the left transverse process compared to the right (palpated while the seated patient maintained a protrusion of the mandible). These findings increased the probability that a mechanical dysfunction in the spine could be the origination of her problems.

Passive mobility assessment was performed to obtain an impression about segmental mobility. Occipito-atlantal (OA) mobility was assessed by cradling the head and making a side-bend motion around a virtual pivot point through the mouth [40]. Testing revealed hypomobility of the left OA joint. Atlanto-axial (AA) mobility was assessed using the cervical flexion-rotation test (FRT). During the FRT the neck is placed in maximum forward bend position. At that point rotation of the head in both directions is compared for range, measured with the

Table 1. Test procedures and outcomes for cervico-thoracic range of motion assessment.

\begin{tabular}{|c|c|c|c|c|}
\hline & Assessment method & Visit 1 & Visit 4 & Visit 9 \\
\hline Pain & VAS & 84 & 48 & 5 \\
\hline Disability & NDI & 68 & 38 & 6 \\
\hline Forward Bend & $\begin{array}{l}\text { Patient seated in upright position with corrected } \\
\text { neutral position. Motion is viewed from behind } \\
\text { and repeated while measured with inclinometer. }\end{array}$ & $\begin{array}{l}40^{\circ} \text {. } \\
\text { Deviated to the right side } \\
\text { and causing uncomfortable } \\
\text { tightness in the } \\
\text { cervicothoracic junction. }\end{array}$ & $\begin{array}{l}53^{\circ} \\
\text { Deviated to the right } \\
\text { minimally. } \\
\text { No pain }\end{array}$ & $\begin{array}{l}72^{\circ} \\
\text { No deviation noted } \\
\text { Pain free }\end{array}$ \\
\hline Backward Bend & $\begin{array}{l}\text { Patient seated in upright position with corrected } \\
\text { neutral posture. Motion is viewed from behind } \\
\text { and repeated while measured with inclinometer. }\end{array}$ & $\begin{array}{l}15^{\circ} \\
\text { Limited by pain. }\end{array}$ & $\begin{array}{l}28^{\circ} \\
\text { Pain at end range }\end{array}$ & $\begin{array}{l}40^{\circ} \\
\text { No pain notedl }\end{array}$ \\
\hline Side bending & $\begin{array}{l}\text { Patient seated in upright position with corrected } \\
\text { neutral posture. Motion is viewed from behind } \\
\text { and repeated while measured with inclinometer. }\end{array}$ & $\begin{array}{l}\text { Left: } 32^{\circ} \\
\text { Right: } 40^{\circ}\end{array}$ & $\begin{array}{l}\text { Left: } 40^{\circ} \\
\text { Right: } 45^{\circ}\end{array}$ & $\begin{array}{l}\text { Left: } 72^{\circ} \\
\text { Right: } 49^{\circ}\end{array}$ \\
\hline Rotation & $\begin{array}{l}\text { Patient in upright seated position. Use of } \\
\text { goniometer to measure motion. The nose } \\
\text { position is used as the reference point relative to } \\
\text { the acromion to the side of rotation. }\end{array}$ & $\begin{array}{l}\text { Left: } 42^{\circ} \\
\text { pain at end range right side of } \\
\text { the neck } \\
\text { Right: } 65^{\circ}\end{array}$ & $\begin{array}{l}\text { Left: } 50^{\circ} \\
\text { Sensitive at end range right } \\
\text { side of the neck } \\
\text { Right: } 68^{\circ}\end{array}$ & $\begin{array}{l}\text { Left: } 72^{\circ} \\
\text { Painfree } \\
\text { Right: } 74^{\circ}\end{array}$ \\
\hline $\begin{array}{l}\text { Suboccipital } \\
\text {-Rotation }\end{array}$ & $\begin{array}{l}\text { Neck flexion test. Patient in supine. Maximal } \\
\text { passive flexion is achieved followed by rotation } \\
\text { of the head. Measurement with goniometer with } \\
\text { the nose position being the reference point. }\end{array}$ & $\begin{array}{l}\text { Left: } 15^{\circ} \\
\text { Painful and provoking the } \\
\text { headache } \\
\text { Right: } 39^{\circ}\end{array}$ & $\begin{array}{l}\text { Left: } 28^{\circ} \\
\text { and painful } \\
\text { Right: } 46^{\circ}\end{array}$ & $\begin{array}{l}\text { Left: } 44^{\circ} \\
\text { No pain upon testing } \\
\text { Right: } 46^{\circ}\end{array}$ \\
\hline $\begin{array}{l}\text { Suboccipital } \\
\text {-side bending }\end{array}$ & $\begin{array}{l}\text { Patient in the supine position. The head is } \\
\text { cradled and side bend motion of the head is } \\
\text { achieved through a virtual pivot point in the } \\
\text { mouth. }\end{array}$ & $\begin{array}{l}\text { Side bend right restricted and } \\
\text { painful }\end{array}$ & $\begin{array}{l}\text { Right equals left motion } \\
\text { without pain }\end{array}$ & \\
\hline $\begin{array}{l}\text { Intervertebral motion testing } \\
\text { Motion assessment grading: } \\
\text { 0- ankylosis. 1-Considerable Restriction. } \\
\text { 2-Slight restriction. 3- Normal } \\
\text { movement. 4-Slight increased movement. } \\
\text { 5-Considerable increased movement. } \\
\text { 6-Unstable }\end{array}$ & $\begin{array}{l}\text { Patient in the supine position. Each segment } \\
\text { underwent an upslide and down slide motion } \\
\text { and end-feel was tested. }\end{array}$ & $\begin{array}{l}\text { AO (L): } 2 / 6 \\
\text { AA (R): } 1 / 6 \\
\text { C2-C3 (R): } 2 / 6 \\
\text { C5-C6 (R): } 2 / 6 \\
\text { T3-T5 (B): } 2 / 6\end{array}$ & $\begin{array}{l}\text { AA (R): } 2 / 6 \\
\text { C5-C6 (R): } 2 / 6 \\
\text { T3-T5 (B): } 2 / 6\end{array}$ & $\begin{array}{l}\text { T4-T5 (B): } 2 / 6 \\
\text { All previously restricted } \\
\text { segments returned to } 3 / 6 \\
\text { mobility }\end{array}$ \\
\hline
\end{tabular}


goniometer and the quality of endfeel [38].The reliability of The FRT in patients with cervicogenic headaches has been demonstrated by Hall et al. [41]. Based on a high sensitivity (90-91\%), specificity (88$90 \%$ ), and overall diagnostic accuracy (91\%) this an appropriate test to use clinically $[7,41]$. Testing revealed hypomobility of the AA joint $(\mathrm{R}>\mathrm{L})$, with headache provocation upon testing thereby increasing the probability that the AA joint limitation was a contributing factor to her $\mathrm{CH}$. Spinal segmental motion assessment was used to further analyze joint mechanics in the cervical spine. The validity and reliability of spinal segmental motion palpation ranges from good to poor [42-45]. It has been proposed that a clinician should be able to identify motion between two different vertebrae through segmental motion assessment [45]. Facet mobility of C2 through C7 was assessed using a down slide test as described by Paris [40] and revealed hypomobility of the right facet joints of C2-C3, C5-C6. Thoracic mobility testing demonstrated hypomobility of T3-T5 (Table 1).

Forward head posture will lead to muscle adaptation in a predictable pattern. Janda [46] identified these changes and described them as "the upper crossed muscle syndrome" [47]. Manual muscle testing was performed as described by Kendall and Magee, which confirmed the presence of "the upper crossed syndrome" [39,48]. Testing revealed marked weakness of the short neck flexors, graded 3+/5 [49]. Left lateral bend of the cervical spine was graded 4/5. Both the rhomboids and middle trapezius were graded 4/5. Muscle length testing demonstrated muscle shortening of the suboccipital region, levator scapula, trapezius, and pectoralis muscle groups, right more than left.

\section{Clinical impression}

Based on the clinical presentation it was hypothesized that this patient presented with a positional default of atlas in right rotation which lead to abnormal mechanical functioning of the cervical and upper thoracic spine resulting in ongoing headaches and alterations in the normal muscle strength/length relationship in the upper quadrant. This rotatory position could have resulted in referred pain from the AA joint complex or causing direct irritation of the $\mathrm{C} 2$ ganglion in the right subocciptal triangle, either caused by muscle tone or by narrowing of the intervertebral space between atlas and axis as a result of the default position of atlas.

The goal of her physical therapy treatment was to normalize atlas position, restore mechanical functioning of the cervical spine, normalize muscular functioning of the upper quadrant and improve upright posturing. The overall aim was to resume her activities of daily living and recreational activities without pain or headaches. Her prognosis was good.

\section{Intervention and outcome}

This patient presented with a relative acute complaint with high tissue sensitivity based on pain limiting active motion. Therefore, the treatment plan included a range of manual techniques (Table 2). Myofascial manipulation was used as a preparatory technique. Muscle energy techniques consisting of a de-rotation technique of atlas to the left and thrust joint manipulation techniques were used to restore normal joint functioning in the subcranial, lower cervical, and upper thoracic facet joints [20]. Additionally, she received active stability training of the cervical-thoracic regions to normalize muscular functioning and she was instructed how to improve her upright posture. The patient was seen for a total of 9 visits. Manipulation techniques used during the course of treatment were performed as described by Hartman and were based on the presence of hypomobility [50]. During the first treatment, a muscle energy technique was used to neutralize atlas position and improve right AA mobility (Figure 2) [20]. The patient was supine with the head in a slight extension and some left rotation with the subject looking left while the remainder of the neck remained in midline. In this position a 6 second light resistance was applied to the left temple to facilitate a left rotational movement of atlas by contraction of the both the left obliquuscapitis superior and inferior muscles. This was followed by a 6 second resistance to the right temple to facilitate a similar left rotation of atlas by contraction of the right rectus capitis anterior muscles. This alternating sequence was repeated 6 times and palpation of the sub-occipital region was performed to ensure that contraction in the sub-occipital region was achieved. After this the head was placed in more extension and left rotation and the above described sequence was repeated. Test-retest using the FRT revealed an increase in left rotation of AA by 5 degrees without headache provocation. To address the hypomobilities of the right facet joint of C5-C6 and T3-T5 segments thrust manipulation was performed in the supine position. In order to maximize the carryover of her interventions the patient was instructed in an augmented exercise program (Table 2), which included the same muscle energy technique she underwent during treatment performed in sitting.

During the second treatment thrust manipulation of the left AO, and right facet joint of $\mathrm{C} 2-\mathrm{C} 3$ were added. Based on the FRT and position palpation of atlas during the third and fourth session the muscle energy of the right AA was repeated and manipulation of the right facet joint of C5-C6 was carried out. The fifth session was two weeks after the initial treatment and, at that time, the right AA joint continued to be stiff and the muscle energy technique was used to address this. Additionally, a supine thrust manipulation was carried out for the T3 through T5 segments [27]. At session six and seven no positional was present and only hypomobility of the T4-T5 segment was detected and thrust manipulation was used to address this. At visit eight and nine no joint limitations were detected; therefore, no joint manipulation techniques were used.

Muscle stretching using the hold-relax technique was used for the posterior neck muscles, levator scapula, trapezius, and pectoralis muscles during the course of treatments. Muscle strengthening focused initially on the supine deep neck flexion exercise, which has been previously described in detail [51] and seated isometric side bending while maintaining a neutral cervical and head position. As the patient progressed, strengthening of the middle, lower trapezius, and rhomboid muscles in the prone position were added to her treatment program (Table 2). The patient was introduced to posture awareness early on and this was reinforced in all subsequent treatments.

After nine treatments the patient no positional default could be identified and she displayed normal AROM of the neck without any provocation of pain (Table 1). She reported that her headaches were no longer present. Her physical therapy goals had been met and she was discharged with the instruction to continue working on her posture correction.
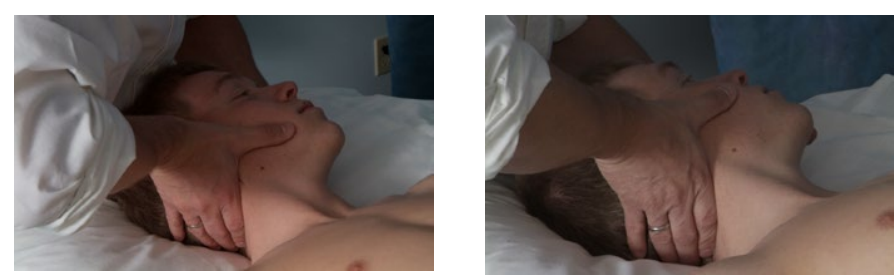

Figure 2. Supine de-rotation technique (not actual patient). 
Table 2. Intervention for each nine visits.

\begin{tabular}{|c|c|c|c|c|c|c|c|c|c|}
\hline & Visit 1 & Visit 2 & Visit 3 & Visit 4 & Visit 5 & Visit 6 & Visit 7 & Visit 8 & Visit 9 \\
\hline Joint manipulation & $\begin{array}{l}\text { C5-C6 (r) } \\
\text { T3-T5 (r) }\end{array}$ & $\begin{array}{l}\mathrm{AO}(1) \\
\mathrm{C} 3-\mathrm{C} 4(\mathrm{r}) \\
\mathrm{C} 5-\mathrm{C} 6(\mathrm{r})\end{array}$ & C5-C6 (r) & T3-T5 (r) & T3-T5 (r) & T3-T5 (r) & T4-T5 (r) & & \\
\hline $\begin{array}{l}\text { Muscle energy de-rotation } \\
\text { technique }\end{array}$ & $\begin{array}{l}\text { To improve left } \\
\text { rotation of atlas }\end{array}$ & $\begin{array}{l}\text { To improve left } \\
\text { rotation of atlas }\end{array}$ & $\begin{array}{l}\text { To improve left } \\
\text { rotation of atlas }\end{array}$ & $\begin{array}{l}\text { To improve left } \\
\text { rotation of atlas }\end{array}$ & $\begin{array}{l}\text { To improve left } \\
\text { rotation of atlas }\end{array}$ & & & & \\
\hline $\begin{array}{l}\text { Myofascial techniques(to } \\
\text { reduce overall muscle } \\
\text { tone) }\end{array}$ & $\begin{array}{l}\text {-Cervical } \\
\text { laminar release } \\
\text {-SCM technique } \\
\text {-Anterior chest } \\
\text { fascial stretch }\end{array}$ & $\begin{array}{l}\text {-Cervical } \\
\text { laminar release } \\
\text {-Anterior chest } \\
\text { fascial stretch } \\
\text {-Pectoralis } \\
\text { muscle play }\end{array}$ & $\begin{array}{l}\text {-Cervical } \\
\text { laminar release } \\
\text {-Pectoralis } \\
\text { muscle play }\end{array}$ & $\begin{array}{l}\text {-Cervical } \\
\text { laminar release } \\
\text {-Pectoralis } \\
\text { muscle play }\end{array}$ & $\begin{array}{l}\text {-Cervical } \\
\text { laminar release } \\
\text {-Pectoralis } \\
\text { muscle play }\end{array}$ & $\begin{array}{l}\text {-Cervical } \\
\text { laminar release } \\
\text {-Pectoralis } \\
\text { muscle play }\end{array}$ & $\begin{array}{l}\text {-Cervical } \\
\text { laminar release }\end{array}$ & $\begin{array}{l}\text {-Cervical } \\
\text { laminar release }\end{array}$ & \\
\hline $\begin{array}{l}\text { Active stabilization } \\
\text { (10 reps } 10 \text { seconds unless } \\
\text { fatigue prevented proper } \\
\text { performance) }\end{array}$ & \begin{tabular}{l|}
-Neck flexion \\
-Isometric neck \\
side bend
\end{tabular} & $\begin{array}{l}\text {-Neck flexion } \\
\text {-Isometric neck } \\
\text { side bend }\end{array}$ & $\begin{array}{l}\text {-Neck flexion } \\
\text {-Isometric neck } \\
\text { side bend }\end{array}$ & $\begin{array}{l}\text {-Neck flexion } \\
\text {-Isometric neck } \\
\text { side bend }\end{array}$ & $\begin{array}{l}\text {-Neck flexion } \\
\text {-Inferior/ } \\
\text { middle trapezius } \\
\text {-Rhomboids }\end{array}$ & $\begin{array}{l}\text {-Neck flexion } \\
\text {-Inferior/ } \\
\text { middle trapezius } \\
\text {-Rhomboids }\end{array}$ & $\begin{array}{l}\text {-Neck flexion } \\
\text {-Inferior/ } \\
\text { middle trapezius } \\
\text {-Rhomboids }\end{array}$ & $\begin{array}{l}\text {-Neck flexion } \\
\text {-Inferior/ } \\
\text { middle trapezius } \\
\text {-Rhomboids }\end{array}$ & $\begin{array}{l}\text {-Neck flexion } \\
\text {-Inferior/ } \\
\text { middle trapezius } \\
\text {-Rhomboids }\end{array}$ \\
\hline $\begin{array}{l}\text { Muscle stretching } \\
\text { (contract-hold-relax- } \\
\text { stretch technique with } \\
3 x 30 \text { second stretch) }\end{array}$ & -Posterior neck & $\begin{array}{l}\text {-Posterior neck } \\
\text { Trapezius, } \\
\text { Levator, } \\
\text { Pectoralis }\end{array}$ & $\begin{array}{l}\text {-Posterior neck } \\
\text { Trapezius, } \\
\text { Levator, } \\
\text { Pectoralis }\end{array}$ & $\begin{array}{l}\text {-Posterior neck } \\
\text { Trapezius, } \\
\text { Levator, } \\
\text { Pectoralis }\end{array}$ & $\begin{array}{l}\text {-Posterior neck } \\
\text { Trapezius, } \\
\text { Levator, } \\
\text { Pectoralis }\end{array}$ & $\begin{array}{l}\text {-Posterior neck } \\
\text { Trapezius, } \\
\text { Levator, } \\
\text { Pectoralis }\end{array}$ & $\begin{array}{l}\text {-Trapezius, } \\
\text { Levator, } \\
\text { Pectoralis }\end{array}$ & $\begin{array}{l}\text {-Trapezius, } \\
\text { Levator, } \\
\text { Pectoralis }\end{array}$ & $\begin{array}{l}\text {-Trapezius, } \\
\text { Levator, } \\
\text { Pectoralis }\end{array}$ \\
\hline $\begin{array}{l}\text { Posture } \\
\text { With visual feedback }\end{array}$ & $\begin{array}{l}\text {-Initiate } \\
\text { awareness }\end{array}$ & $\begin{array}{l}\text {-Sub occipital } \\
\text { positioning }\end{array}$ & $\begin{array}{l}\text {-Sub occipital } \\
\text { positioning } \\
\text {-TSA } \\
\text { positioning }\end{array}$ & $\begin{array}{l}\text {-Sub occipital } \\
\text { positioning } \\
\text {-Head } \\
\text { positioning } \\
\text {-TSA } \\
\text { positioning }\end{array}$ & $\begin{array}{l}\text {-Sub occipital } \\
\text { positioning } \\
\text {-Head } \\
\text { positioning } \\
\text {-TSA } \\
\text { positioning }\end{array}$ & $\begin{array}{l}\text {-Sub occipital } \\
\text { positioning } \\
\text {-Head } \\
\text { positioning } \\
\text {-TSA } \\
\text { positioning }\end{array}$ & $\begin{array}{l}\text {-Sub occipital } \\
\text { positioning } \\
\text {-Head } \\
\text { positioning } \\
\text {-TSA } \\
\text { positioning }\end{array}$ & $\begin{array}{l}\text {-Sub occipital } \\
\text { positioning } \\
\text {-Head } \\
\text { positioning } \\
\text {-TSA } \\
\text { positioning }\end{array}$ & $\begin{array}{l}\text {-Sub occipital } \\
\text { positioning } \\
\text {-Head } \\
\text { positioning } \\
\text {-TSA } \\
\text { positioning }\end{array}$ \\
\hline $\begin{array}{l}\text { Augmented Home } \\
\text { exercises } \\
\text { (stretched hold for } \\
30 \text { seconds } x 3 \text { and } \\
\text { strengthening } 10 x 10 \\
\text { seconds ifpossibel) }\end{array}$ & $\begin{array}{l}\text {-Posterior neck } \\
\text { stretch } \\
\text {-Cervical } \\
\text { rotation in max } \\
\text { flexion } \\
\text {-Muscle energy } \\
\text { de-rotation } \\
\text { technique. } \\
\text {-Neck flexion } \\
\text { strengthening } \\
\text {-Posture } \\
\text { correction }\end{array}$ & $\begin{array}{l}\text {-Cervical } \\
\text { rotation in max } \\
\text { flexion } \\
\text {-Muscle energy } \\
\text { de-rotation } \\
\text { technique. } \\
\text {-Posterior neck, } \\
\text { Trapezius, } \\
\text { and Pectoralis } \\
\text { stretching } \\
\text {-Neck flexion } \\
\text { strengthening } \\
\text {-Posture } \\
\text { correction }\end{array}$ & $\begin{array}{l}\text {-Cervical } \\
\text { rotation in max } \\
\text { flexion } \\
\text {-Muscle energy } \\
\text { de-rotation } \\
\text { technique. } \\
\text {-Posterior neck, } \\
\text { Trapezius, } \\
\text { and Pectoralis } \\
\text { stretching } \\
\text {-Neck flexion } \\
\text { strengthening } \\
\text {-Posture } \\
\text { correction }\end{array}$ & $\begin{array}{l}\text {-Cervical } \\
\text { rotation in max } \\
\text { flexion } \\
\text {-Muscle energy } \\
\text { de-rotation } \\
\text { technique. } \\
\text {-Posterior neck, } \\
\text { Trapezius, } \\
\text { and Pectoralis } \\
\text { stretching } \\
\text {-Neck flexion } \\
\text { strengthening } \\
\text {-Posture } \\
\text { correction }\end{array}$ & $\begin{array}{l}\text {-Cervical } \\
\text { rotation in max } \\
\text { flexion } \\
\text {-Muscle energy } \\
\text { de-rotation } \\
\text { technique. } \\
\text {-Posterior neck, } \\
\text { Trapezius, } \\
\text { and Pectoralis } \\
\text { stretching } \\
\text {-Neck flexion } \\
\text { and scapular } \\
\text { strengthening } \\
\text {-Posture } \\
\text { correction }\end{array}$ & $\begin{array}{l}\text {-Cervical } \\
\text { rotation in max } \\
\text { flexion } \\
\text {-Muscle energy } \\
\text { de-rotation } \\
\text { technique. } \\
\text {-Posterior neck, } \\
\text { Trapezius, } \\
\text { and Pectoralis } \\
\text { stretching } \\
\text {-Neck flexion } \\
\text { and scapular } \\
\text { strengthening } \\
\text {-Posture } \\
\text { correction }\end{array}$ & $\begin{array}{l}\text {-Cervical } \\
\text { rotation in max } \\
\text { flexion } \\
\text {-Muscle energy } \\
\text { de-rotation } \\
\text { technique. } \\
\text {-Posterior neck, } \\
\text { Trapezius, } \\
\text { and Pectoralis } \\
\text { stretching } \\
\text {-Neck flexion } \\
\text { and scapular } \\
\text { strengthening } \\
\text {-Posture } \\
\text { correction }\end{array}$ & $\begin{array}{l}\text {-Cervical } \\
\text { rotation in max } \\
\text { flexion } \\
\text {-Muscle energy } \\
\text { de-rotation } \\
\text { technique. } \\
\text {-Posterior neck, } \\
\text { Trapezius, } \\
\text { and Pectoralis } \\
\text { stretching } \\
\text {-Neck flexion } \\
\text { and scapular } \\
\text { strengthening } \\
\text {-Posture } \\
\text { correction }\end{array}$ & $\begin{array}{l}\text {-Cervical } \\
\text { rotation in max } \\
\text { flexion } \\
\text {-Muscle energy } \\
\text { de-rotation } \\
\text { technique. } \\
\text {-Posterior neck, } \\
\text { Trapezius, } \\
\text { and Pectoralis } \\
\text { stretching } \\
\text {-Neck flexion } \\
\text { and scapular } \\
\text { strengthening } \\
\text {-Posture } \\
\text { correction }\end{array}$ \\
\hline
\end{tabular}

\section{Outcomes}

The patient was seen for a total of 9 visits during a 5-week time span. Comparison of the AROM measures, VAS, and NDI scores at baseline, session 4 and session 9 can be found in Table 1. At session four, side bending, and rotation left remained restricted. Suboccipital rotation left improved to $28^{\circ}$ but continued to provoke pain. At session nine AROM was pain free. Suboccipital rotation was pain free; and rotation seemed fairly equal during the FRT. Intervertebral joint mobility in the cervical spine and T3-T4 was restored to normal and only the right facet joint of T4-T5 remained stiff. At session four, her VAS score decreased to $46 \mathrm{~mm}$. The NDI score by session four had improved to 38. At session nine, she reported that she was no longer experiencing any headaches and she felt that her neck moved much better, without any pain and her ability to remain upright was improving, although this remained challenging. Her VAS score was only $0.5 \mathrm{~mm}$ and her NDI score improved to 6 . During a 2-month follow-up phone call the patient reported she had maintained her headache-free status.

\section{Discussion}

Joint dysfunctions can contribute to neck pain and headaches
$[52,53]$. They can be the result of pathological conditions of the joint itself, problems with the supporting muscles and connective tissues, or nerve tissues [54]. It appeared that the patient in this case displayed joint dysfunctions at multiple segments. Based on the clinical findings it was hypothesized that the positional default of atlas was the primary source of this patient's problem. Therefore proper identification of anatomical landmarks in the suboccipital region is necessary. The C2 spinous process can be identified by palpating midline below the external occipital protuberance [55]. The transverse process of atlas is located anterior of the mastoid process and posterior of the ramus of the mandible [20]. By protruding the ramus the transverse process becomes easily accessible. Bilateral simultaneous palpation of the transverse process of atlas will provide a direct impression of its relative position in comparison to the occiput and the rest of the cervical spine. To validate this palpation techniques it will have to be compared with outcomes of other validated diagnostic tests, such as radiographs [42]. Evaluation of her cervical radiograph (Figure 1) confirmed the presence of a rotated atlas. As seen on the lateral view both posterior arches of atlas are visualized, which can only occur when atlas is not placed in the horizontal plane. This concurred with the palpation findings, therefore supporting the hypothesis of a rotatory atlas default position [24]. 
Further studies will be necessary to determine the content validity of this approach to determine atlas position.

Joint Manipulation has been shown to be effective $[27,56,57]$ in the management of patients with neck pain [40,46,58-60]; therefore, it could have contributed to the improvements reported in this case. The effects of manipulation is beyond biomechanical changes only [61]; however, in the current literature there is no clear explanation for some of the effects of manipulation [62]. A few hypotheses have been proposed offering mechanical, neurophysiological, and psychological rationales $[62,63]$. Considering anatomical relationships and the mechanical forces used during manipulations it can't be ruled out that there was a direct positive effect on the central nervous system in this case causing neurophysiological responses and thereby affecting her pain and headaches $[61,62,64]$.

Panjabi [13] suggests that in the neutral zone little resistance is offered by the ligamentous system to maintain cervical stability; therefore, changes in the supporting cervical musculature may lead to pain patterns often found in patients with neck pain and headaches $[34,36,65]$. It has been demonstrated that stimulation of ligaments can increase paraspinal muscles activity [66]. Therefore, it seems plausible to assume that a similar effect can be caused by the stabilizing ligaments of the high cervical region following trauma or postural deficits, causing an increased activity of the stabilizing muscles of this region. This increased muscle activity, or spasm, of the anterior and posterior sub-occipital muscles might maintain the rotatory default position of atlas. A combination of manual therapy techniques including a muscle energy de-rotation technique and direct manipulation of the spine appeared beneficial restoring the position of atlas and normalize subocciptital joint functioning [20].

\section{Conclusion}

To our knowledge this is the first report postulating that a positional default position of atlas can exist and could be a contributing factor in subjects with $\mathrm{CH}$. This case illustrates the successful management using manual therapy, including a de-rotation technique of atlas for the treatment of cervicogenic headache and cervical pain following a whiplash trauma. Evaluation techniques for the high cervical spine including palpation for position and movement in combination with the assessment of a lateral radiograph of the cervical spine lead to the hypothesis that this patient presented with a rotatory positional default of atlas. Further research is necessary to test the hypothesis that the positional default of atlas could play a role in patients with neck pain and headaches. Additionally, the cause-effect relationship between the treatment and positive outcome in this case study has to be further validated.

\section{References}

1. Headache Classification Subcommittee of the International Headache Society (2004) The International Classification of Headache Disorders: (2ndedn), Cephalalgia 24: 9-160.[Crossref]

2. Nilsson N (1995) The prevalence of cervicogenic headache in a random population sample of 20-59 year olds. Spine (Phila Pa 1976) 20: 1884-1888.[Crossref]

3. Sjaastad O, Bakketeig L (2008) Tension-type headache: comparison with migraine without aura and cervicogenic headache. The Våga study of headache epidemiology. Funct Neurol 23: 71-76.[Crossref]

4. Sjaastad O, Bakketeig LS (2008) Prevalence of cervicogenic headache: Vågå study of headache epidemiology. Acta Neurol Scand 117: 173-180.[Crossref]

5. Haldeman S, Dagenais S (2001) Cervicogenic headaches: a critical review. Spine $J 1$ : 31-46.[Crossref]
6. Aprill C, Axinn MJ, Bogduk N (2002) Occipital headaches stemming from the lateral atlanto-axial (C1-2) joint. Cephalalgia 22: 15-22.[Crossref]

7. Ogince M, Hall T, Robinson K, Blackmore AM (2007) The diagnostic validity of the cervical flexion-rotation test in C1/2-related cervicogenic headache. Man Ther 12: 256262.[Crossref]

8. Lu J, Ebraheim NA (1998) Anatomic considerations of C2 nerve root ganglion. Spine (Phila Pa 1976) 23: 649-652.[Crossref]

9. Bilge $\mathrm{O}$ (2004) An anatomic and morphometric study of $\mathrm{C} 2$ nerve root ganglion and its corresponding foramen. Spine (Phila Pa 1976) 29: 495-499.[Crossref]

10. Cattrysse E, Barbero M, Kool P, Gagey O, Clarys JP, et al. (2007) 3D morphometry of the transverse and alar ligaments in the occipito-atlanto-axial complex: an in vitro analysis. Clin Anat 20: 892-898.[Crossref]

11. Zhang H, Bai J (2007) Development and validation of a finite element model of the occipito-atlantoaxial complex under physiologic loads. Spine (Phila Pa 1976) 32: 968974.[Crossref]

12. Panjabi MM (1992) The stabilizing system of the spine. Part II. Neutral zone and instability hypothesis. J Spinal Disord 5: 390-396.[Crossref]

13. Panjabi MM, Crisco JJ, Vasavada A, Oda T, Cholewicki J, et al. (2001) Mechanica properties of the human cervical spine as shown by three-dimensional loaddisplacement curves. Spine (Phila Pa 1976) 26: 2692-2700.[Crossref]

14. Crisco JJ 3rd, Panjabi MM, Dvorak J (1991) A model of the alar ligaments of the upper cervical spine in axial rotation. J Biomech 24: 607-614. [Crossref]

15. Goel VK, Clark CR, Gallaes K, Liu YK (1988) Moment-rotation relationships of the ligamentous occipito-atlanto-axial complex. J Biomech 21: 673-680.[Crossref]

16. Putz R, Sobotta PR (2000) Atlas van de menselijkeanatomie. Vol 1. Houten/ Diegem Bohn Staflue Van Loghum.

17. Kahle W, Leonhardt H, Platzer W (1979)Sesam Atlas van de anatomieVol 1. Baarn Bosch \&Keuning NV.[Crossref]

18. Grant T, Niere K (2000) Techniques used by manipulative physiotherapists in the management of headaches. Aust J Physiother 46: 215-222.[Crossref]

19. Hack GD, Koritzer RT, Robinson WL, Hallgren RC, Greenman PE (1995) Anatomic relation between the rectus capitis posterior minor muscle and the dura mater. Spine (Phila Pa 1976) 20: 2484-2486.[Crossref]

20. Rocabado M (2007) Cranio-Fascial 32007.

21. Fielding JW, Hawkins RJ (1977) Atlanto-axial rotatory fixation. (Fixed rotatory subluxation of the atlanto-axial joint). J Bone Joint Surg Am 59: 37-44.[Crossref]

22. Mihara H, Onari K, Hachiya M, Toguchi A, Yamada K (2001) Follow-up study of conservative treatment for atlantoaxial rotatory displacement. J Spinal Disord 14: 494 499. [Crossref]

23. Villas C, Arriagada C, Zubieta JL (1999) Preliminary CT study of C1-C2 rotational mobility in normal subjects. Eur Spine J 8: 223-228.[Crossref]

24. Fielding JW, Hawkins RJ (1977) Atlanto-axial rotatory fixation. (Fixed rotatory subluxation of the atlanto-axial joint). J Bone Joint Surg Am 59: 37-44.[Crossref]

25. Bird SB, Dickson EW (2001) Clinically significant changes in pain along the visual analog scale. Ann Emerg Med 38: 639-643.[Crossref]

26. Gallagher EJ, Liebman M, Bijur PE (2001) Prospective validation of clinically important changes in pain severity measured on a visual analog scale. Ann Emerg Med 38: 633-638.[Crossref]

27. Cleland JA, Childs JD, McRae M, Palmer JA, Stowell T (2005) Immediate effects of thoracic manipulation in patients with neck pain: a randomized clinical trial. Man Ther 10: 127-135.[Crossref]

28. Vernon H, Mior S (1991) The Neck Disability Index: a study of reliability and validity J Manipulative Physiol Ther 14: 409-415.[Crossref]

29. Riddle D, Stratford P (1998) Use of generic versus region-specific functional status measures on patients with cervial spine disorders. Phys Ther 78: 951-963.[Crossref]

30. Cleland JA, Fritz JM, Whitman JM, Palmer JA (2006) The reliability and construct validity of the Neck Disability Index and patient specific functional scale in patients with cervical radiculopathy. Spine (Phila Pa 1976) 31: 598-602.[Crossref]

31. Finch E, Brooks D, Stratford P, Mayo N (2002) Physical Rehabilitation Outcome Measures, A Guide to Enhanced Clinical Decision Making second ed. Ontario: BC Decker. 
32. Raine S, Twomey LT (1997) Head and shoulder posture variations in 160 asymptomatic women and men. Arch Phys Med Rehabil 78: 1215-1223.[Crossref]

33. Wright EF, Domenech MA, Fischer JR Jr (2000) Usefulness of posture training for patients with temporomandibular disorders. J Am Dent Assoc 131: 202-210.[Crossref]

34. Fernández-de-Las-Peñas C, Cuadrado ML, Pareja JA (2006) Myofascial trigger points, neck mobility and forward head posture in unilateral migraine. Cephalalgia 26: 10611070.[Crossref]

35. Yip CH, Chiu TT, Poon AT (2008) The relationship between head posture and severity and disability of patients with neck pain. Man Ther 13: 148-154.[Crossref]

36. Braun BL, Amundson LR (1989) Quantitative assessment of head and shoulder posture. Arch Phys Med Rehabil 70: 322-329.[Crossref]

37. Watson DH, Trott PH (1993) Cervical headache: an investigation of natural head posture and upper cervical flexor muscle performance. Cephalalgia 13: 272-284. [Crossref]

38. Piva SR, Erhard RE, Childs JD, Browder DA (2006) Inter-tester reliability of passive intervertebral and active movements of the cervical spine. Man Ther 11: 321-330. [Crossref]

39. Magee D (2002) Orthopedic Physical Assessment. 4 ed. Philadelphia: Saunders.

40. Paris S (2000) S1 course notes2000; Chicago.

41. Hall TM, Robinson KW, Fujinawa O, Akasaka K, Pyne EA (2008) Intertester reliability and diagnostic validity of the cervical flexion-rotation test. J Manipulative Physiol Ther 31: 293-300.[Crossref]

42. Seffinger MA, Najm WI, Mishra SI, Adams A, Dickerson VM, et al. (2004) Reliability of spinal palpation for diagnosis of back and neck pain: a systematic review of the literature. Spine (Phila Pa 1976) 29: E413-425.[Crossref]

43. Humphreys B, Delahaye M, Peterson C (2004)An investigation into the validity of cervical spine motion palpation using subjects with congenital block vertebrae as a 'gold standard'. BMC Musculoskelet Disord 5: 19.[Crossref]

44. Degenhardt BF, Snider KT, Snider EJ, Johnson JC (2005) Interobserver reliability of osteopathic palpatory diagnostic tests of the lumbar spine: improvements from consensus training. J Am Osteopath Assoc 105: 465-473.[Crossref]

45. Christensen HW, Vach W, Vach K, Manniche C, Haghfelt T, et al. (2002) Palpation of the upper thoracic spine: an observer reliability study. J Manipulative Physiol Ther 25: 285-292.[Crossref]

46. Cantu R, Grodin A (2001)Myofascial Manipulation, Theory and Clinical application second edition. Gaithersburg, Maryland: Aspen publications.

47. Moore MK (2004) Upper crossed syndrome and its relationship to cervicogenic headache. J Manipulative Physiol Ther 27: 414-420.[Crossref]

48. Kendall F, McCreary E, Provance P, Rodgers M, Romani W (2005) Muscles Testin and Function with Posture and Pain. (5thedn.), Philadelphia: Lippincott Williams and Wilkins.

49. Edmondston SJ, Wallumrød ME, Macléid F, Kvamme LS, Joebges S, et al. (2008) Reliability of isometric muscle endurance tests in subjects with postural neck pain. $J$ Manipulative Physiol Ther 31: 348-354.[Crossref]
50. Hartman L (1997) Handbook of Osteopathic Technique. (3rdedn.), Cheltenham: Stamley Thornes Ltd.

51. Petersen SM (2003) Articular and muscular impairments in cervicogenic headache: a case report. J Orthop Sports Phys Ther 33: 21-30.[Crossref]

52. Paris S, Loubert P (1997) FCO Foundations of Clinical Orthopaedics: Institue Press

53. Lin RM, Tsai KH, Chu LP, Chang PQ (2001) Characteristics of sagittal vertebral alignment in flexion determined by dynamic radiographs of the cervical spine. Spine (Phila Pa 1976) 26: 256-261.[Crossref]

54. Hollerwöger D (2006) Methodological quality and outcomes of studies addressing manual cervical spine examinations: a review. Man Ther 11: 93-98.[Crossref]

55. Snodgrass S, Rivett DA, Robertson VJ (2007) Manual Forces Applied During Cervical Mobilization. J Manipulative Physiol Ther 30: 17-25.[Crossref]

56. Gonzalez-Iglesias J, Fernandez-De-Las-Penas C, Cleland J, Alburquerque-Sedin F, Palomeque-del-Cerro L, et al. (2008) Inclusion of Thoracic spine thrust manipulation into an electro-therapy/thermal program for the management of patients with acute mechanical neck pain: A Randomized clinical trial. Man Ther [Epub ahead of print]: 1-8.[Crossref]

57. Astin JA, Ernst E (2002) The effectiveness of spinal manipulation for the treatment of headache disorders: a systematic review of randomized clinical trials. Cephalalgia 22 617-623.[Crossref]

58. Winkel D (1996) Diagnosis and Treatment of the Spine. Gaithersburg, Maryland Aspen Publishers, Inc.

59. Van der ElA, Lunacies P, Wagemaker A (1993) Manuele Therapies. Rotterdam Manuel.

60. Kerry R, Taylor A, Mitchell J, McCarthy C, Brew J (2008) Manual Therapy and Cervical Arterial Dysfunction, Directions for the Future: A Clinical Perspective. J Man Manip Ther 16: 39-48.[Crossref]

61. Bialosky JE, Bishop MD, Robinson ME, George SZ (2010) The relationship of the audible pop to hypoalgesia associated with high-velocity, low-amplitude thrust manipulation: a secondary analysis of an experimental study in pain-free participants. $J$ Manipulative Physiol Ther 33: 117-124.[Crossref]

62. Bialosky JE, Bishop MD, Price DD, Robinson ME, George SZ (2009) The mechanisms of manual therapy in the treatment of musculoskeletal pain: a comprehensive model. Man Ther 14: 531-538.[Crossref]

63. Dishman J, Greco D, Burke J (2008) Motor-Evoked Potentials Recorded from Lumbar Erector Spinae Muscles: A Study of Corticospinal Excitability Changes Associated with Spinal Manipulation. J Manipulative Physiol Ther 31:258-269.[Crossref]

64. Bialosky JE, Bishop MD, Robinson ME, Zeppieri G Jr, George SZ (2009) Spinal manipulative therapy has an immediate effect on thermal pain sensitivity in people with low back pain: a randomized controlled trial. Phys Ther 89: 1292-1303.[Crossref]

65. Fernández-de-Las-Peñas C, Alonso-Blanco C, Cuadrado ML, Gerwin RD, Pareja JA (2006) Myofascial trigger points and their relationship to headache clinical parameters in chronic tension-type headache. Headache 46: 1264-1272.[Crossref]

66. Solomonow M, Zhou BH, Harris M, Lu Y, Baratta RV (1998) The ligamento-muscular stabilizing system of the spine. Spine (Phila Pa 1976) 23: 2552-2562.[Crossref]

Copyright: (C2015 Sillevis R. This is an open-access article distributed under the terms of the Creative Commons Attribution License, which permits unrestricted use, distribution, and reproduction in any medium, provided the original author and source are credited. 